\title{
The goosefoot in the air of selected Polish cities in 2018
}

\author{
Małgorzata Malkiewicz', Kazimiera Chłopek ${ }^{2}$, Katarzyna Dąbrowska-Zapart², Barbara Gałusza", \\ Dariusz Jurkiewicz ${ }^{3}$, Ewa Kalinowska4, Agnieszka Lipiec ${ }^{5}$, Dorota Myszkowska', \\ Krystyna Piotrowska-Weryszko7, Małgorzata Puc ${ }^{8,9}$, Adam Rapiejk04, 10, Grzegorz Siergiejko", \\ Alina Stacewicz ${ }^{8},{ }^{9}$, Aneta Sulborska ${ }^{7}$, Kornel Szczygielski ${ }^{3}$, Zenon Siergiejko' ${ }^{12}$, Krystian Tywoniuk ${ }^{13}$, \\ Monika Ziemianin ${ }^{6}$, Piotr Rapiejko ${ }^{3,4}$ \\ ${ }^{1}$ Laboratory of Paleobotany, Department of Stratigraphical Geology, Institute of Geological Sciences, \\ University of Wroclaw, Poland \\ 2 Faculty of Earth Sciences, University of Silesia, Sosnowiec, Poland \\ ${ }^{3}$ Department of Otolaryngology with Division of Cranio-Maxillo-Facial Surgery in Military Institute of Medicine, \\ Warsaw, Poland \\ ${ }^{4}$ Allergen Research Center Ltd., Warsaw, Poland \\ ${ }^{5}$ Department of Prevention of Environmental Hazards and Allergology, Medical University of Warsaw, Poland \\ ${ }^{6}$ Department of Clinical and Environmental Allergology, Jagiellonian University Medical College, Cracow, Poland \\ Department of General Ecology, University of Life Sciences, Lublin, Poland \\ ${ }^{7}$ Department of Botany, University of Life Sciences, Lublin, Poland \\ ${ }^{8}$ Department of Botany and Nature Conservation, Faculty of Biology, University of Szczecin, Poland \\ ${ }^{9}$ Molecular Biology and Biotechnology Centre, Faculty of Biology, University of Szczecin, Poland \\ ${ }^{10}$ Oxford Archaeology Ltd., Oxford, England \\ ${ }_{11}$ Pediatrics, Gastroenterology and Allergology Department, University Children Hospital, \\ Medical University of Bialystok, Poland \\ ${ }^{12}$ Laboratory of Respiratory Diagnostics and Bronchoscopy, Medical University of Bialystok \\ ${ }^{13}$ Department of Otolaryngology, Audiology and Phoniatrics, Children's Hospital of Bydgoszcz
}

\section{Abstract:}

This paper presents the course of goosefoot pollination in selected cities of Poland in 2018. The measurements were performed in Bialystok, Bydgoszcz, Cracow, Drawsko Pomorskie, Lublin, Olsztyn, Opole, Piotrkow Trybunalski, Sosnowiec, Szczecin, Warsaw, Wroclaw, and Zielona Gora. Volumetric method with the use of Volumetric Spore Trap (Burkard, Lanzoni) was implemented. In the studied cities in 2018, pollen season of goosefoot started in the third decade of May and ended in the third decade of September. Goosefoot pollen stayed in the air for more than 100 days - 142 days in Sosnowiec and 109 days in Bialystok. Maximum daily concentration $\left(26 \mathrm{P} / \mathrm{m}^{3}\right)$ was noticed in Bialystok, although the lowest - in Cracow $\left(7 \mathrm{P} / \mathrm{m}^{3}\right)$. In the majority of the measuring points the highest moment of pollen season was in August. The highest number of pollen grains in 2018 was found in Lublin (478 grains), the lowest - in Cracow (149 grains). The concentration above $10 \mathrm{P} / \mathrm{m}^{3}$ was very rare, only in Lublin it was this high for 12 days and in Warsaw for 8 days

Key words: allergens, pollen count, goosefoot, 2018

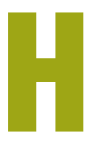
erbaceous plants, which produce strongly allergenic pollen are most importantly grasses and mugwort. Plantain and sorrel pollen belong to the group of a much less allergenic significance.
However goosefoot pollen (same as nettel) doesn't have a very important allergenic significance [1].

Goosefoot (Chenopodium L.) belongs to the Chenopodiaceae family and it is a common weed 
found in whole Europe. In Poland the Chenopodium L. genus includes several species, but the most common one is Chenopodium album L. [2].

Goosefoot is strongly connected with human and his places of settlement. It is an important component of ruderal habitats. As a common weed it occurs in gardens, orchards, scrap-heaps and edges of fields.

Goosefoot blooms for a long time, from June to August [1], or even October [2], but the concentration of its pollen never reaches high numbers. According to Rapiejko [6] highest concentrations in the atmosphere do not reach above $60 \mathrm{P} / \mathrm{m}^{3}$. In comparison nearby plants can reach even $1735 \mathrm{P} / \mathrm{m}^{3}$.

The allergenic significance of goosefoot pollen is minor. The goosefoot pollen rarely cause allergy symptoms, but it becomes important for sufferers of advanced pollinosis [3]. Although it may be a risk of cross reactions with allergens of: Atriplex latifolia, Salsola kali and Amaranthus retroflexus [4].

Aim

The aim of the study was to compare the goosefoot pollen concentration in the air in selected Polish cities: Bialystok, Bydgoszcz, Cracow, Drawsko Pomorskie, Lublin, Olsztyn, Opole, Piotrkow Trybunalski, Sosnowiec, Szczecin, Warsaw, Wroclaw, Zielona Gora in 2018 .

\section{Material and method}

In 2018, the measurements of the pollen concentration in the study sites were performer with the volumetric method using Burkard and Lanzoni pollen samplers. Microscopic observations were performed on preparations obtained in a 7-day cycle with assessment of 24-hour periods. The date of maximum concentration of goosefoot pollen and the number of days during which concentration was above 10 and $20 \mathrm{P} / \mathrm{m}^{3}$ were appointed. Because of the low concentration there was no beginning and ending of the pollen season using statistic methods. The course of the pollen concentrations in each city is shown in the graphs (figs 1-5).

\section{The results}

Goosefoot pollen in the air of selected cities in 2018 appeared between May $30^{\text {th }}$ and June $5^{\text {th }}$. There

Figure 1. Goosefoot pollen count in Bialystok, Lublin and Warsaw in 2018.

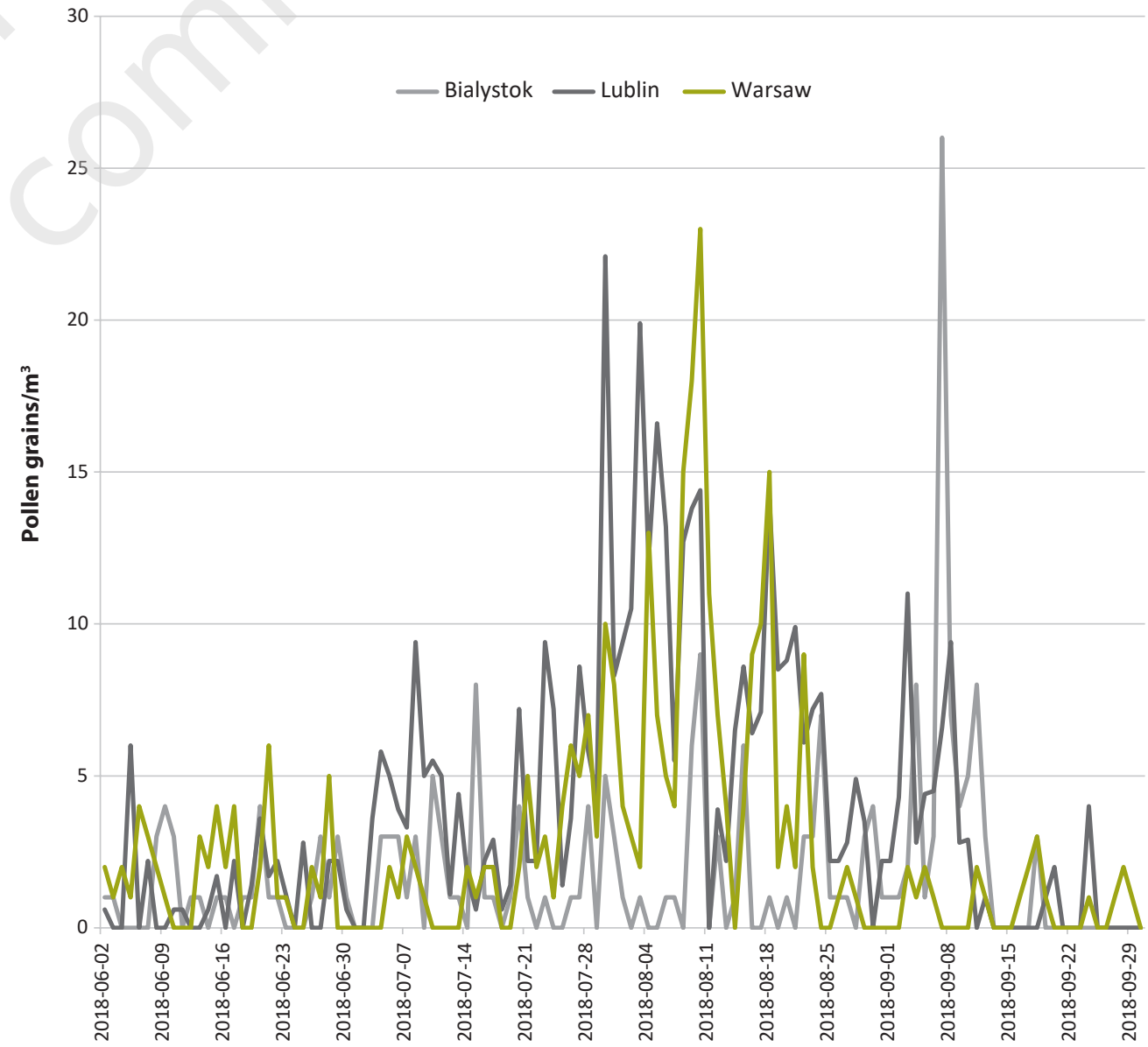


Figure 2. Goosefoot pollen count in Wroclaw, Opole and Sosnowiec in 2018.

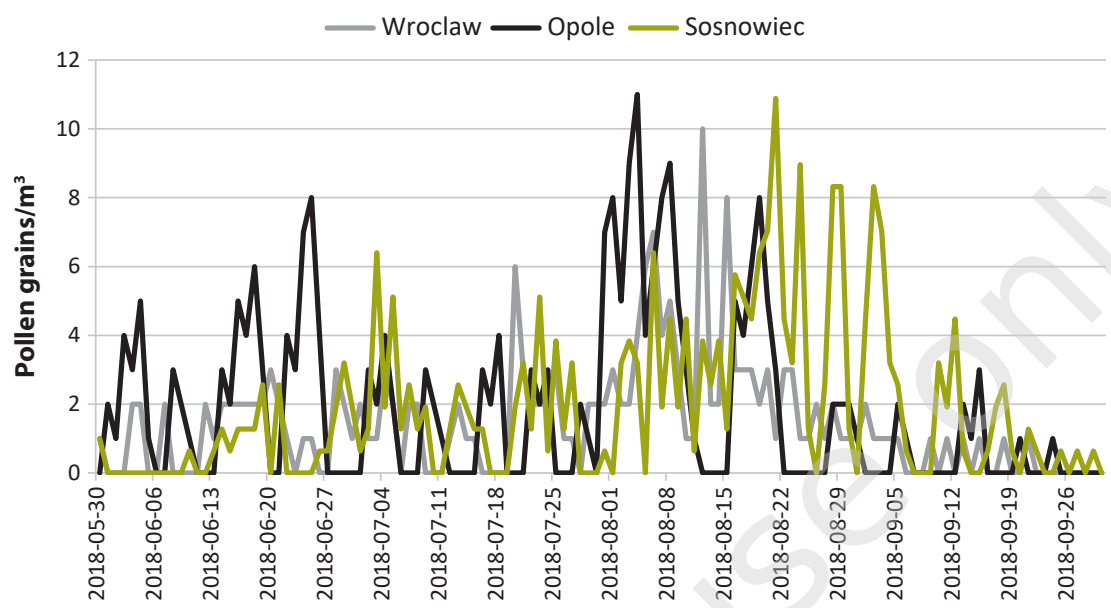

Figure 3. Goosefoot pollen count in Zielona Gora, Cracow and Drawsko Pomorskie in 2018.

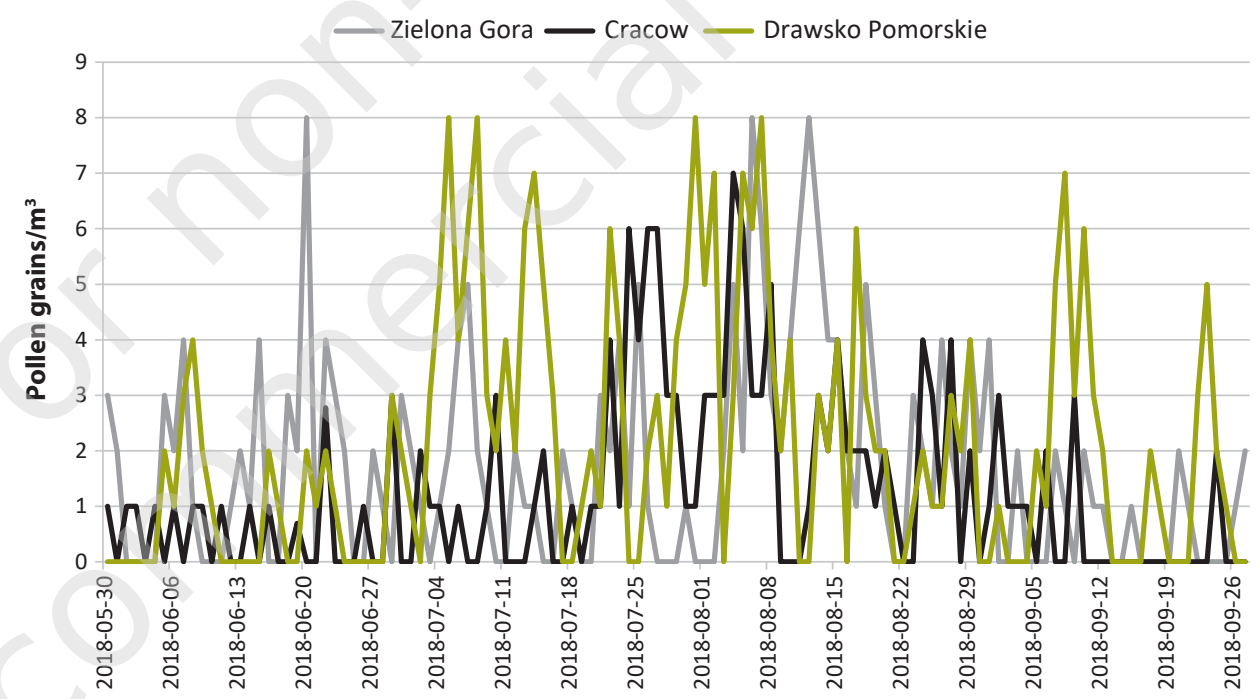

Figure 4. Goosefoot pollen count in Olsztyn and Bydgoszcz in 2018.

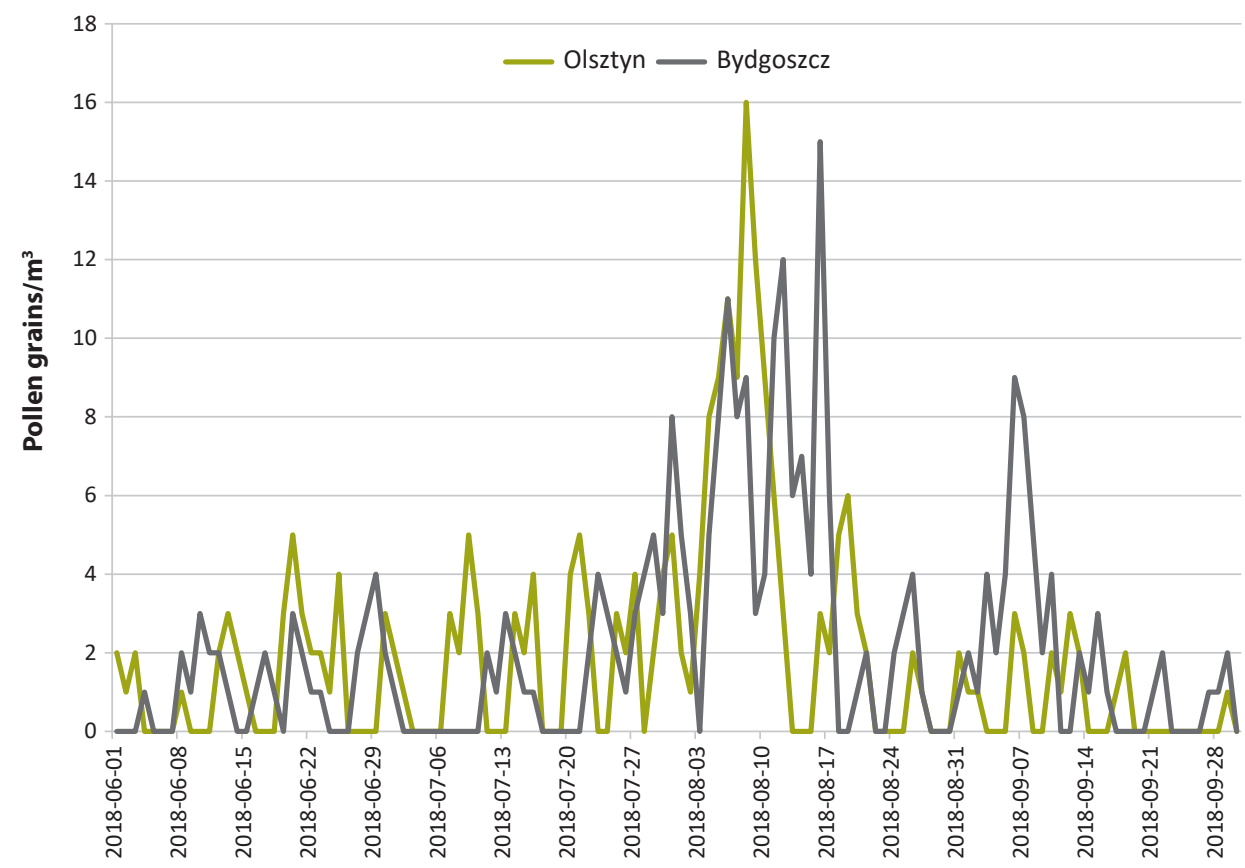


Figure 5. Goosefoot pollen count in Szczecin and Piotrkow Trybunalski in 2018.

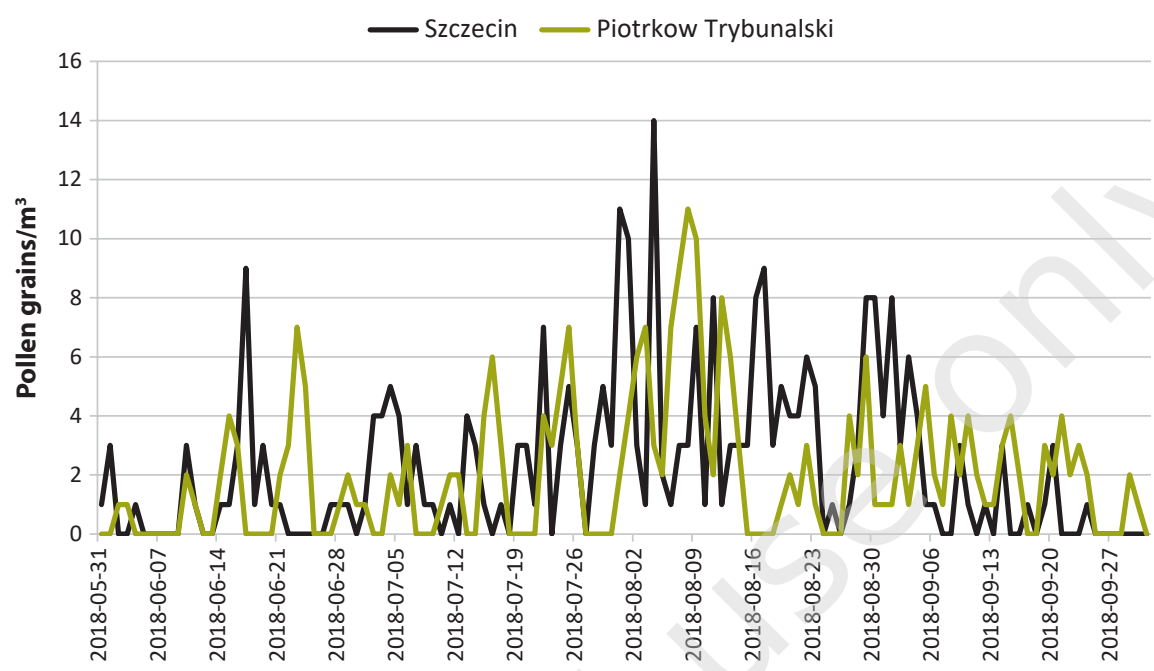

were 4 cities in which the pollen appeared the earliest Cracow, Sosnowiec, Wroclaw and Zielona Gora. The last city in which goosefoot pollen appeared was Drawsko
Pomorskie. In Bialystok, Lublin, Piotrkow Trybunalski and Warsaw pollination begun simultaneously - June $2^{\text {nd }}$, although in Opole and Szczecin May $31^{\text {st }}$ (tab. 1).

Table 1. Characteristics of goosefoot pollen season in 2018.

\begin{tabular}{|c|c|c|c|c|}
\hline Site & $\begin{array}{l}\text { Maximum pollen count }\left(\mathrm{P} / \mathrm{m}^{3}\right) \\
\text { (date) }\end{array}$ & $\begin{array}{l}\text { Seasonal Pollen Index SPI } \\
\text { (total) }\end{array}$ & $\begin{array}{l}\text { Days number above threshold } \\
\qquad 10 \mathrm{P} / \mathrm{m}^{3}\end{array}$ & $\begin{array}{l}\text { Days number above threshold } \\
\qquad 20 \mathrm{P} / \mathrm{m}^{3}\end{array}$ \\
\hline Bialystok & $\begin{array}{c}26 \\
7.09\end{array}$ & 214 & 1 & 1 \\
\hline Bydgoszcz & $\begin{array}{c}15 \\
16.08\end{array}$ & 265 & 4 & - \\
\hline Cracow & $\begin{array}{c}7 \\
4.08\end{array}$ & 149 & - & - \\
\hline $\begin{array}{l}\text { Drawsko } \\
\text { Pomorskie }\end{array}$ & $\begin{array}{c}8 \\
5.07 / 8.07 / 31.07 / 7.08\end{array}$ & 261 & - & - \\
\hline Lublin & $\begin{array}{c}22 \\
30.07\end{array}$ & 478 & 12 & 2 \\
\hline Olsztyn & $\begin{array}{c}16 \\
8.08\end{array}$ & 229 & 3 & - \\
\hline Opole & $\begin{array}{c}11 \\
4.08\end{array}$ & 233 & 1 & - \\
\hline $\begin{array}{l}\text { Piotrkow } \\
\text { Trybunalski }\end{array}$ & $\begin{array}{c}11 \\
8.08\end{array}$ & 246 & 2 & - \\
\hline Sosnowiec & $\begin{array}{c}11 \\
21.08\end{array}$ & 243 & 1 & - \\
\hline Szczecin & $\begin{array}{c}14 \\
4.08\end{array}$ & 282 & 3 & - \\
\hline Warsaw & $\begin{array}{c}23 \\
10.08\end{array}$ & 319 & 8 & 1 \\
\hline Wroclaw & $\begin{array}{c}10 \\
12.08\end{array}$ & 183 & 1 & - \\
\hline $\begin{array}{l}\text { Zielona } \\
\text { Gora }\end{array}$ & $\begin{array}{c}8 \\
20.06 / 6.08 / 12.08\end{array}$ & 204 & - & - \\
\hline
\end{tabular}


The last grains of goosefoot pollen were found between September $18^{\text {th }}$ in Bialystok and October $18^{\text {th }}$ in Sosnowiec. Goosefoot pollen stays in the air for a very long time and it is included in the group of long-term pollen seasons with several maximum values [5]. In all of the studied cities in 2018 goosefoot pollen stayed in the air for more than 100 days. For the longest time - 142 days - in Sosnowiec. For the shortest period of time - 109 days - in Bialystok.

Maximum concentration of goosefoot pollen in 2018 was varied, it fluctuated between $7 \mathrm{P} / \mathrm{m}^{3}$ in Cracow and $26 \mathrm{P} / \mathrm{m}^{3}$ in Bialystok (tab. 1; figs 1, 3). Highest concentrations in given cities were noticed in August (between $4^{\text {th }}$ and $21^{\text {st }}$ ). Only in Bialystok the maximum daily concentration occurred at the beginning of September (fig. 1). In 2011 the maximum concentration occurred much earlier - even in the first decade of July [6]. In Drawsko Pomorskie and Zielona Gora there was no one maximum concentration (fig. 3). In those cities it was registered that the numbers were highest for 3-4 days $\left(8 \mathrm{P} / \mathrm{m}^{3}\right)$. Those days occurred between second decade of June and second decade of August (tab. 1).

Annual amounts of concentrations of goosefoot pollen in 2018 were proportional to the values of maximal concentrations. SPI index was the highest in Lublin (478 grains). In other cities SPI balanced between 149 grains in Cracow, 183 grains in Wroclaw, 204 grains in Zielona Gora, 214 grains in Bialystok and even more than 220 grains in Bydgoszcz, Drawsko Pomorskie, Olsztyn, Opole, Piotrkow Trybunalski, Sosnowiec, Szczecin and Warsaw (319 grains) (tab. 1). In 2018 the annual amount in Bydgoszcz, Drawsko Pomorskie and Warsaw was almost two times lower and in Szczecin even three times lower than in 2011 [6]. However in Sosnowiec it was noticed that the annual amount was almost two times higher comparing to 2011.

The number of days with the concentration above $10 \mathrm{P} / \mathrm{m}^{3}$ balanced between 1 (in Bialystok, Opole, Sosnowiec and Wroclaw) to 12 in Lublin. In three of the studied cities (Cracow, Drawsko Pomorskie, Zielona Gora) daily concentrations of goosefoot pollen in the whole pollen season were below $10 \mathrm{P} / \mathrm{m}^{3}$. The period of concentration above $20 \mathrm{P} / \mathrm{m}^{3}$ was 2 days in Lublin and 1 day in Bialystok and Warsaw.

Despite the fact that 2018 was relatively warm and dry (with a small amount of rainfall) the amount of goosefoot pollen in the air still got higher (both the maximum daily concentrations and the annual amount). Maximum concentrations noticed in 2018 were slightly low (in some cities even few times lower than in years
2011-2012) [6, 7], thereby, the exposure to goosefoot allergens was small. Therefore, the medical significance of goosefoot allergens in symptoms of allergic rhinitis is relatively small.

\section{Conclusions}

Goosefoot pollen in 2018 in studied cities stayed in the air from the end of May until the third decade of September and first days of October.

The highest daily concentration $\left(26 \mathrm{P} / \mathrm{m}^{3}\right)$ was noticed in Bialystok, although the lowest in Cracow $\left(7 \mathrm{P} / \mathrm{m}^{3}\right)$.

In the majority of measuring points the peak pollen season was in August.

The highest annual amount was found in Lublin (478 grains), the lowest in Cracow (149 grains).

In most of the studied cities the number of days during which concentration was above $10 \mathrm{P} / \mathrm{m}^{3}$ was really low (did not exceeded 4 days); only in Lublin the number of days was 12 and in Warsaw 8.

\section{References}

1. Rapiejko P. Alergeny pyłku roślin. Medical Education, Warszawa 2007.

2. Szafer W, Kulczyński S, Pawłowski B. Rośliny polskie. Wyd. Naukowe PWN, Warszawa 1988.

3. Rapiejko P. Plant pollen allergens. Alerg Astma Immunol 1997, 2(1): 9-18.

4. Rapiejko P. Alergeny pytku komosy. Alergoprofil 2009, 5(1): 42-43.

5. Kasprzyk I. Sezonowe zmiany koncentracji ziaren pyłku w powietrzu. In: Weryszko-Chmielewska E (ed). Aerobiologia. Wyd. Akademii Rolniczej, Lublin 2007.

6. Chłopek K, Weryszko-Chmielewska E, Piotrowska K et al. Pytek komosy w powietrzu wybranych miast Polski w 2011 roku. Alergoprofil 2012, 8(1): 51-54.

7. Lipiec A, Puc M, Malkiewicz M et al. Analiza stężenia pyłku komosy w wybranych miastach Polski w 2012 roku. Alergoprofil 2012, 8(3): 43-46.

\section{ORCID}

M. Malkiewicz - ID - orcid.org/0000-0001-6768-7968

K. Dąbrowska-Zapart - ID - orcid.org/ 0000-0002-8976-7739

B. Gałusza - ID - orcid.org/ 0000-0002-9594-5108

E. Kalinowska - ID - orcid.org/ 0000-0003-4821-6882

A. Lipiec - ID - orcid.org/0000-0003-3037-2326

D. Myszkowska - ID - orcid.org/ 0000-0002-1493-3990

K. Piotrowska-Weryszko - ID - orcid.org/ 0000-0003-3827-3218

M. Puc - ID - orcid.org/0000-0001-6734-9352

K. Szczygielski - ID - orcid.org/ 0000-0002-3717-5424

K. Tywoniuk - ID - orcid.org/0000-0002-4610-0002

M. Ziemianin - ID - orcid.org/ 0000-0003-4568-8710

P. Rapiejko - ID - orcid.org/ 0000-0003-3868-0294 
Author's contributions: Malkiewicz M: 50\%. and other Authors: $277 \%$ each. Conflict of interests: The authors declare that they have no competing interests. Financial support: Research in Bialystok, Bydgoszcz, Olsztyn, Opole, Zielona Gora, Piotrkow Trybunalski and Warsaw funded by Allergen Research Center Ltd. (Ośrodek Badania Alergenów Środowiskowych Sp. z 0.0.)

Ethics: The contents presented in this paper are compatible with the rules the Declaration of Helsinki, EU directives and standardized requirements for medical journals.
Corresponding author:

Malgorzata Malkiewicz, PhD

Laboratory of Paleobotany, Institute of Geological Sciences, University of Wroclaw 50-205 Wroclaw, Cybulskiego 34 e-mail: malgorzata.malkiewicz@uwr.edu.pl 